Ана Јанковић

Народна библиотека Бор ana.jankovic67@gmail.com
Прегледни рад

UDK 007:027.54]:004(497.11)

616.98:578.834(100)"2020"

https://doi.org/10.18485/bibliotekar.2020.62.2.5

\title{
ЈАВНЕ БИБЛИОТЕКЕ И ЫИХОВА ДЕЛАТНОСТ У ВРЕМЕ ПАНДЕМИЈСКЕ КРИЗЕ
}

Сажетак: У овом раду биће речи о јавним библиотекама и њиховом деловању у измењеним условима због проглашења опасности од заразне болести ковид-19, а пре свега о активностима Народне библиотеке Бор током ванредног стања и након њега. Јавне библиотеке су морале да пронађу начин да наставе свој рад и превладају првобитне страхове у вези са опречним информацијама и да се често саме суоче са тешким избором око тога које услуге и како понудити корисницима, у распону од минималних ограничења до потпуног затварања. Са друге стране, већи број корисника је, да би задовољио своје потребе и интересовања, морао да се окрене онлајн изворима и услугама, тако да се у раду истражује и ефекат нових услова рада Библиотеке на коришћење дигитализоване грађе и виртуелних библиотечких услуга и система. Библиотеке ће морати добро да размотре своје могућности и ресурсе и да свој рад и програме прилагоде ономе што је људима најпотребније. Како се ток пандемије непрекидно мења, библиотеке треба да се усредсреде на појачавање своје виртуелне понуде и да пронађу начин да то буде уз минимални трошак који ће моћи да поднесу, пошто су се готово све јавне библиотеке у Србији већ суочиле са смањењем годишњег буџета.

Кључне речи: јавна библиотека, пандемија, библиотечки ресурси, корисничке навике, онлајн услуге.

\section{Увод: нека инострана искуства}

Природне катастрофе, ратови, заразне болести, одувек прете опстанку човечанства. О последњој која је задесила читав свет, пандемији вируса короне, говори се и пише готово годину дана, откад су први случајеви заразе забележени у Кини. Последњих месеци, о до сада непознатом вирусу, много се више зна и о њему ће одлучујућу реч свакако дати медицински научници. И док вирус тресе светску економију, здравствене системе, 
политику, школство, приватни и друштвени живот, ни култура не може да буде поштеђена. Вероватно ће једном бити написане и бројне анализе о утицају и последицама социјалне дистанце, као једне од главних прописаних мера за сузбијање и спречавање ширења заразе и као узрока измењених услова рада библиотека у свету. Ово се нарочито односи на јавне библиотеке које су у потпуности отворене и окренуте својим корисницима и које су, у највећем броју, након званичне објаве пандемије - биле принуђене да затворе врата за кориснике, што је у мирнодопско време прилично неуобичајена ситуација. Након почетног несналажења и лутања и покушаја да се корисници „не оставе на цедилу” и да се настави пружање библиотечких услуга у складу са прописаним мерама за отклањање или смањење ризика, које су подразумевале хигијенске, санитарне, здравствене, организационе и едукативно-промотивне мере, чије су спровођење, строгост и опсежност увелико зависили, пре свега, од спремности и организованости њихових државних система и грађанског друштва да прихвате и финансирају овакву измењену стварност у којој култура није била међу приоритетима, многе библиотеке су се, потом, окренуле својим другим расположивим ресурсима, па иако су одустале од непосредног рада са корисницима, омогућиле су друге начине да се виталне услуге библиотеке и даље користе, само на другачији, безбедан начин - у смислу смањивања могућности ширења заразе.

Већина је одмах понудила своје онлајн колекције и наставила да комуницира са корисницима на различите начине који нису подразумевали непосредни контакт: отворили су телефонске линије, организовали контакте преко различитих онлајн апликација и остале и даље ойворене за сва питања и информисање корисника. Многе користе друштвене мреже да би обавестиле јавност о различитим библиотечким онлајн ресурсима и специјалним понудама за бесплатан или ограничен приступ интернету. Такође, обавестили су своје кориснике да не брину што имају невраћену грађу јер се накнада неће наплаћивати док су библиотеке затворене.

Удружење јавних библиотека (PLA - Public Library Association), ${ }^{1}$ професионално удружење библиотекара јавних библиотека и присталица, посвећених развоју и ефикасности запослених у јавним библиотекама у пружању библиотечких услуга у Сједињеним Америчким Државама, спровело је истраживање у 2.545 јавних библиотека широм земље (што представља $28 \%$ свих јавних библиотека у САД) о томе како јавне библиотеке реагују

1 Public Library Association, http://www.ala.org/pla/ 
на пандемију вируса SARS-CoV-2 (вирус корона). Већина испитаника (98\%) одговорила је да су њихове зграде затворене за кориснике, али библиотекари настављају да пружају библиотечке услуге заједници на најиновативније начине: проширили су приступе свим дигиталним ресурсима, покренули виртуелне програме, бесплатне вебинаре и ангажовали се у заједничким акцијама са локалним владиним агенцијама. ${ }^{2}$

Занимљива је измењена пракса у једној малој библиотеци у Белгији, ${ }^{3}$ управо зато што међу богатим искуствима библиотекара, доступним на интернету, ово умногоме подсећа на наше, у Србији, па и у самој Народној библиотеци Бор. Као и многе белгијске библиотеке и јавна библиотека у градићу Питему затворена је за јавност, али од почетка априла, у договору са корисницима који им имејлом шаљу спискове грађе коју желе да позајме, библиотекари то припреме и спаковано у кесе оставе на улазу у библиотеку. Кажу да нису ограничили број грађе која се може позајмити, али нико то није злоупотребљавао. Пошто је реч о малој библиотеци у средини која има око 6.700 становника, дневно припреме око осам пакета. Води се рачуна о томе да размак између долазака буде 30 минута, како би се избегао истовремени боравак више људи у холу библиотеке. Корисници су са захвалношћу и одобравањем дочекали покретање ове библиотечке услуге јер у време када су друштвени контакти ограничени, према њиховим речима, књиге и филмови су им много значили да прекрате време. Тражене су популарне књиге, познати аутори или књиге на основу којих су снимљене серије, а веома су популарни и стрипови.

Да би се успорило ширење вируса короне, и у Немачкој су средином марта све јавне и научне библиотеке затворене за кориснике. Тиме је онемогућена позајмица свих аналогних медија, а манифестације и окупљања у библиотекама су отказани. Како би се корисницима и надаље омогућило коришћење информација и медија, запослени у око 10.000 библиотека широм Немачке давали су свима који су заинтересовани информације телефоном или онлајн. Осим тога, свим пријављеним корисницима библиотека̂ и даље су на располагању били многобројни електронски медији - електронске књиге, дигиталне новине и часописи, аудио-књиге, уџбеници,

„How Public Libraries Are Responding to the Pandemic”, American Libraries Magazine, April 9, 2020, https://americanlibrariesmagazine.org/blogs/the-scoop/public-libraries-respondingpandemic/ (preuzeto 5. 9. 2020).

3 NAPLE Sister Libraries, „Libraries in Times of Coronavirus: the Case of Public Library of Pittem (Belgium), https://www.naplesisterlibraries.org/libraries-in-times-of-coronavirus-the-case-ofpublic-library-of-pittem-belgium/ (preuzeto 5. 9. 2020). 
филмови, музика, као и онлајн базе података. Да би се што већем броју грађана омогућио приступ грађи и информацијама из веродостојних извора, многе библиотеке су увеле онлајн уписивање у библиотеку, на шта је посебно указало и Немачко библиотечко удружење (DBV - Deutscher Bibliotheksverband), ${ }^{4}$ похваливши ову иницијативу за то да се коришћењем јавне библиотеке за стицање знања и креирање слободног времена олакшају ограничења јавног живота. ${ }^{5}$

\section{Домаћи „матрикс": организација рада Народне библиотеке Бор од 16. марта до 1. септембра 2020. године}

Јавне библиотеке у Србији, за које многи и даље мисле да су застареле и превазиђене установе, у условима пандемије и измењене реалности показале су управо супротно: у потрази за алтернативним решењем за класичну позајмицу књига и остале грађе, углавном ослоњени на сопствено знање и идеје, у непрекидној међусобној комуникацији и уз велику помоћ Библиотекарског друштва Србије, као и подршку националне библиотечке установе - Народне библиотеке Србије, библиотекари су успешно прилагодили пословање и услуге новим захтевима и наставили да раде свој посао, и притом, ако се у обзир узму објективне околности хроничног недостатка средстава и пажње својих оснивача, често препуштени томе да свој рад након проглашења ванредног стања 15. марта 2020. године усклађују са закаснелим прописима и препорукама - нису заостајале за својим колегама у иностранству.

Ипак, бројне контроверзе од самог почетка, па и за све време трајања пандемијске кризе у Србији, наводе на размишљања о томе како је она (корона) изнела на видело, само у другачијем светлу, неке дубоке и изгледа још неиспитане претпоставке о природи и вредности (вредновању?) рада у установама културе - у овом случају, у библиотекама.

4 Deutscher Bibliotheksverband, https://www.bibliotheksverband.de/

5 Deutscher Bibliotheksverband (dbv), „Coronavirus: Bibliotheken bieten weiterhin Zugang zu Information und Medien”, https://wwwbibliotheksverband.de/dbv/presse-details/archive/2020/ march/article/coronavirus-bibliotheken-bieten-weiterhin-zugang-zu-information-und-medien. html (preuzeto 31. 8. 2020). Prevela sa nemačkog Jelena Radovanović. 


\section{Ванредно стање}

Након што је 15. марта проглашено ванредно стање у Републици Србији услед ширења болести ковид-19 изазване вирусом SARS-CoV-2, Народна библиотека Бор је 18. марта, пошто је објављен Закључак владе 05 бр. 53-2561/2020 о обустављању рада са странкама путем непосредног контакта у свим органима државне управе, Аутономне покрајине Војводине и јединица локалне самоуправе, посебним организацијама, УСТАНОВАМА јавним предузећима и другим организацијама којима је оснивач или већински власник Република Србија, аутономна покрајина и јединица локалне самоуправе (Сл. іласник PC, бр. 35/2020), обуставила рад са корисницима, који представља најважнији вид деловања једне јавне библиотеке. Остали послови у библиотеци обављали су се по Одлуци о организацији радног времена у Народној библиотеци Бор током ванредног стања, а на основу прописа донетих у време ванредног стања и наредби и упутстава Штаба за ванредне ситуације Града Бора. Радне околности драстично су се промениле: пре свега, реорганизовано је радно време запослених, тако да се ради само у првој смени; осим обавезе у градском Инфо-центру и Оперативном центру (помагање старијима од 65 година), уведена су и обавезна дежурства у библиотеци за давање свих неопходних информација корисницима у вези са радом Библиотеке. У време ванредног стања неколико пута је искоришћена опција за слање општих електронских обавештења путем Кобиса оним корисницима који су оставили имејл адресе. Једна од тих порука била је и понуда матурантима да им се грађа потребна за матурски рад скенира и пошаље имејлом. Занимљиво, ниједан матурант није искористио ову могућност.

У време трајања ванредног стања, радило се и у ванредним околностима, многе планиране активности отказане су или одгођене, а неке су и реализоване. Корисницима је на располагању била дигитализована завичајна грађа на сајту Завичајног одељења Народне библиотеке Бор „Дигитални завичај"': библиотекар Завичајног одељења Драган Стојменовић истиче да је у ово време приметан раст посета и прегледа садржаја на сајту „Дигитални завичај”; током читаве прошле године забележено је 70.000 посета, а само од 1. јануара до 1. септембра 2020. године - 82.459 посета (укупна посећеност је 494.555).

6 Истакла ауторка текста.

Дигитални завичај, http://www.digitalnizavicaj.org.rs/ 
У исто време, Завичајно одељење учествовало је у пројекту (започетом неколико месеци раније) Биљане Ћирић, историчара уметности и независног кустоса, која живи и ради у Шангају. Реч је о дугорочном (трогодишњем) међународном истраживачком пројекту „As you go... the roads under your feet, towards a new future” („Како идеш/идете... путеви под твојим/вашим ногама, ка новој будућности") у оквиру едукативне платформе „What could/should curating do?” („Шта би кустосирање могло/ требало да ради?"). ${ }^{8}$ Циљ овог занимљивог и за нас у Бору важног пројекта јесте истраживање, разумевање и мултимедијално документовање утицаја и ефеката кинеске државне развојне стратегије, односно стратегије ширења кинеског капитала и утицаја, познате као Појас и йуй (или Јеgан йојас, јеgан $\bar{u} y \bar{u})$ на локалне културе и заједнице у које се „усељавају” кинески радници и кинеска привреда ${ }^{9}$ међу којима се налази и Бор са околином (откад је кинеска рударска компанија „Зиђин” постала већински власник некадашњег Рударско-топионичарског басена Бор). Управо зато, једна од „ћелија” овог пројекта постала је и Народна библиотека Бор ${ }^{10}$ јер се њено Завичајно одељење бави и прикупљањем релевантне грађе и стварањем нових извора у вези са утицајима различитих облика индустријализације, у различитим друштвено-економским и политичко-идеолошким контекстима, на свакодневни живот и рад. Завичајно одељење обезбеђује информације и грађу истраживачима који учествују у два потпројекта - „Студија случаја рудни-

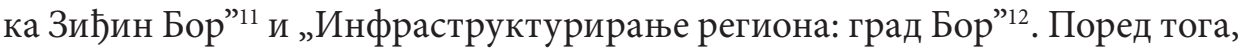
пројекат „As you go...” подразумева и истоимени онлајн часопис у којем је, преведен на енглески језик, објављен текст Драгана Стојменовића „О борском индустријском наслеђу”'13. Текст је настао у време ванредног стања,

8 WHAT COULD/SHOULD CURATING DO?_WCSCD, http://wcscd.com/index.php/aboutwcscd/

9 WHAT COULD/SHOULD CURATING DO? -WCSCD, http://wscsd.com/index.php/about-asyou-go/ (preuzeto 1. 9. 2020).

10 WHAT COULD/SHOULD CURATING DO? -WCSCD, „The Public Library Bor”, http://wscsd. com/index.php/cells/ (preuzeto 1. 9. 2020).

11 WHAT COULD/SHOUld CURATING DO?-WCSCD, Zijin Bor Mining Case Study, http:// wscsd.com/index.php/projects/zijin-bor-mining-case-study/ (preuzeto 1. 9. 2020).

12 WHAT COULD/SHOULD CURATING DO?-WCSCD, Infrastructuring the Region: The City of Bor, http://wscsd.com/index.php/projects/infrastructuring-the-region-the-city-of-bor/ (preuzeto 1.9.2020).

13 WHAT COULD/SHOULD CURATING DO? -WCSCD, „On Bor's Industrial Heritage”, http:// wscsd.com/index.php/wcscd-curatorial-inquiries/as-you-go-journal/on-bors-industrialheritage/ (preuzeto 1. 9. 2020). 
као део опсежне студије фотографске грађе која се чува и обрађује на Завичајном одељењу, у контексту њеног настанка и каснијих коришћења и која се бави претпоставкама и утицајима страног инвестиционог капитала, односно капиталистичких начина индустријализације, и дуго припремане приватизације индустрије у Бору на третман културног наслеђа у јавном простору, при чему је у фокусу индустријско наслеђе. Текст ће, под насловом „Индустријско наслеђе у индустрији наслеђа”, у нешто измењеном и допуњеном облику, бити објављен у публикацији О фотио-gокументиащији Франиускої gрушишва борских руяника (издавач је Народна библиотека Бор), која је у штампи.

И на сајту Народне библиотеке Бор, осим сервисних информација, било је занимљивих садржаја за које су били задужени библиотекари Виолета Стојменовић и Горан Миленковић. Обележен је Светски дан поезије 21. марта, а 23. априла и Светски дан књиге - надасве актуелним и духовитим текстом Гила Партингтона „Прљаве књиге”, ${ }^{14}$ који је са енглеског језика превела Виолета Стојменовић. На сајту је и Горан Миленковић од 22. марта до 1. маја објавио седам прилога представљајући Одељење посебних фондова и периодике, али и три своја ауторска текста; у једном ${ }^{15}$ се, инспирисан фотографијом графита са фашистичким покличем и симболима нашврљаним на једном од експоната рударских машина из некадашњег Парк-музеја на отвореном Музеја рударства и металургије у Бору, присетио есеја „Вечито враћање фашизма” холандског мислиоца Роба Римена.

У исто време припреман је и материјал за двоброј 39-40 Бележнице, која је одштампана средином јула.

\section{Без ванредног стања али уз ванредне мере}

Након скоро два месеца, Народна библиотека Бор од 11. маја поново ради са корисницима. У једној смени, без приступа корисника фондовима, уз обавезне хигијенско-санитарне мере и строго спровођење организационих мера (одржавање прописаног минималног растојања између особа у библиотеци и поштовање препорука и одлука Владе о максималном броју особа у истом простору).

14 Народна библиотека Бор, „Прљаве књиге”, https://www.biblioteka-bor.org.rs/2020/04/povodom-svetskog-dana-knjige/ (преузето 6. 9. 2020).

15 Народна библиотека Бор, „Не учествовати. Не прилагођавати се.”, https://www.bibliotekabor.org.rs/2020/03/ne-ucestvovati-ne-prilagodjavati-se/ (преузето 6. 9. 2020). 
С обзиром на то да су превентивне мере и даље биле на снази, што је онемогућавало уобичајени рад са корисницима, одлучено је да се корисницима максимално излази у сусрет и пружи потпуна помоћ и свака информација која би допринела да ипак добију књиге које желе да читају иако не могу да приђу фондовима. Пре свега, свим корисницима којима није истекло чланство на дан увођења ванредног стања, када је Библиотека затворена на готово два месеца, продужен је рок важења чланарине за та два изгубљена месеца. Књиге су могле да се врате сваког дана, без чланске карте и то тако што су стављане у кутије на улазу у Библиотеку, а библиотекари су их онда одлагали у салу за програме где су чекале у „карантину” пет дана, колико смо, слушајући надлежне и пратећи разне препоруке лекара и научника, проценили да треба да прође да би било безбедно да их поново дамо на коришћење, поготово старијима и деци. Корисницима је понуђено више могућности за наручивање грађе: телефоном, имејлом, преко апликације „Моја библиотека” у Кобису или да лично донесу списак књига које би желели да прочитају. На сајту Народне библиотеке Бор постоје детаљна упутства за претраживање локалног онлајн каталога и коришћење апликација COBISS+ и mCOBISS, а Виолета Стојменовић је направила и веома детаљан списак онлајн књижара и сајтова са препорукама за читање. Једини услови били су да по наручене књиге корисници морају доћи следећег дана (са чланском картом), да не би чекали на малом простору Информативног одељења и да се не ствара гужва док библиотекари траже књиге (простор библиотеке у згради Дома културе има три нивоа) и задужују у Кобису, да у библиотеку улазе један по један и да обавезно носе заштитне маске и дезинфикују руке и обућу на улазу.

Пошто се епидемиолошка ситуација у граду полако поправљала, мало су попустиле и мере, па је у петак 26. јуна уз прописан број присутних, у сали на Информативном одељењу отворена изложба фотографија „Дневник о мами", аутора̂ Стефана и Бошка Ђорђевића, младих уметника из Бора.

\section{Ванредна ситуациа}

Супротно уверавањима о слабљењу интензитета преношења вируса у летњим месецима, у Бору је, као и у многим другим градовима у Србији, поново дошло до погоршања епидемиолошке ситуације, али је овога пута посегнуто за блажом мером: уведена је ванредна ситуација на читавој територији Града Бора. У раду са корисницима није ништа битније мењано, али су сада већ почела и појединачна незадовољства корисника и нервоза због тога што и даље не могу на спрат, у фондове, међу полице и да сами бирају 
књиге. Срећом, ванредна ситуација је укинута после месец дана, тако да од 18. августа, корисници поново могу да улазе на позајмна одељења за одрасле и децу, али са обавезном маском, дезинфекцијом на улазу и без дужих задржавања и групних долазака. Од 1. септембра отворене су и читаонице, могуће је и коришћење рачунара за кориснике. Библиотека поново ради у две смене.

\section{Веза између промењених услова рада библиотеке током пандемије и корисничких навика}

Као библиотекари, до сада смо се много више бавили читалачким навикама и укусима наших корисника, покушавајући да угодимо свима. Сваке године правимо опсежне анализе фондова и коришћења. Зато је недостатак опсежније анализе корисничких навика сада донео нека мала изненађења. Не баш пријатна.

Наиме, Народна библиотека Бор је чланица система COBISS.SR још од 2005. године. Услови да се пређе на аутоматизовану позајмицу стекли су се тек 2017. године. Радили смо, грешили, учили, исправљали и надали се да ће све погодности које доноси онлајн каталог, разне могућности за коришћење таквог система од куће, прихватити и наши корисници. Чињеница да мало њих жели да остави имејл адресу и добија обавештења од библиотеке или да им приликом уписа или касније доделимо шифру за отварање налога помоћу кога ће моћи да управљају својим резервацијама и задужењима, да претражују каталог и „памте” резултате својих претраживања и науче да их користе - није посебно забрињавала, као ни занемарљив број онлајн резервација. Док смо имали стару базу која није била видљива на интернету нити доступна корисницима, имали смо позамашне листе чекања. Зашто се данас не користе предности Кобиса? Своди се на то да нам овај скупи и сложени систем великих могућности служи и даље само за каталогизацију и позајмицу. Тако смо мирно могли и са старом базом. Али нисмо хтели да останемо невидљиви и сами у овом виртуелном свету, јер као ни човек, ни „библиотека није острво”.

Прве трансакције преко апликација COBISS+ и mCOBISS регистроване су 3. марта 2018. године. Само 207 (то је око 9\% активних) чланова, откад је формирана корисничка база у Кобису, користили су онлајн услуге и то су учинили укупно 1.864 пута до сада, што је у просеку девет трансакција по члану. 
Ванредно стање у држави и ванредно стање у Библиотеци били су добра прилика да проучимо навике корисника у вези са онлајн трансакцијама у Кобису и у Библиотеци - да упоредимо како/колико се позајмљивала грађа током периода̂ ванредног стања и ванредне ситуације, који су прилично пореметили и библиотечку и корисничку рутину и праксу у односу на исти период прошле године.

Ради поређења са подацима пре пандемије, за посматрање су узети упоредни периоди од 1. јануара до 1. септембра 2019. и 2020. године.

Анализом су обухваћена оба позајмна одељења - за децу и одрасле и читаоница.

\section{Графикон 1.}

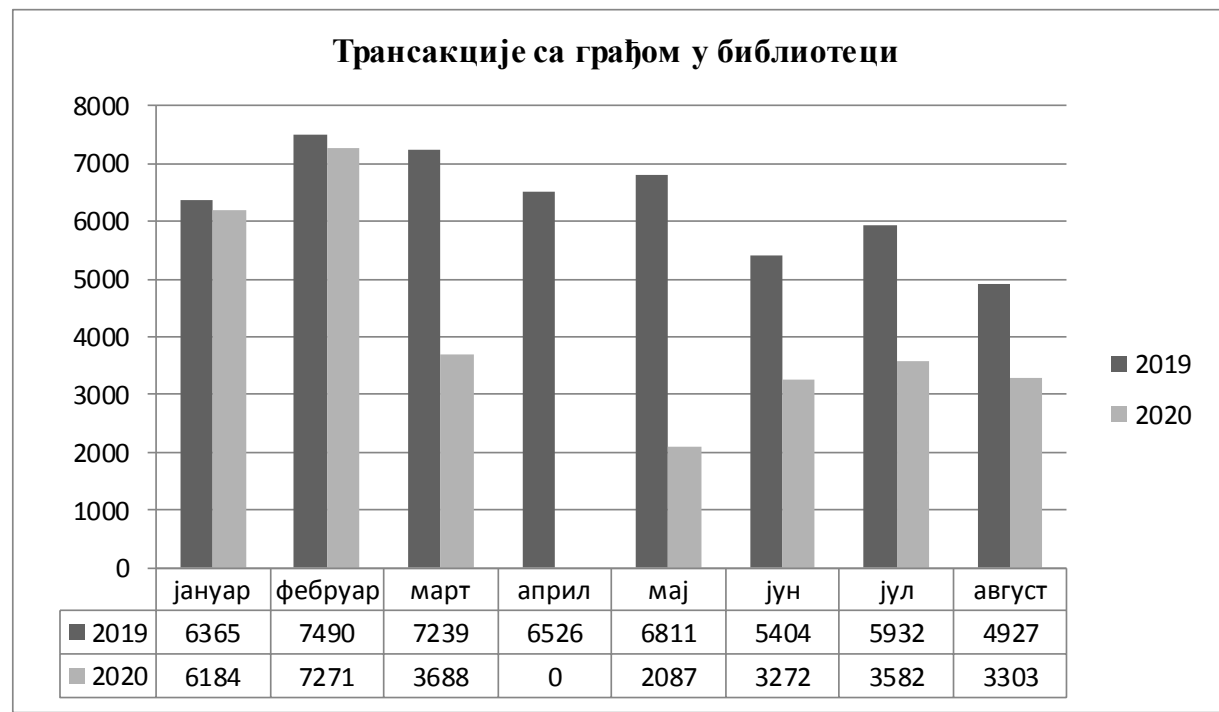

Показатељи исказани бројкама у табелама указују на последице измењене праксе у свакодневном раду са корисницима током ванредног стања (када библиотека није радила са корисницима), као и ванредне ситуације у Бору, уведене након погоршања епидемиолошке ситуације у самом граду, када се опет радило по „ковид систему”, што корисницима Народне библиотеке Бор очигледно или није одговарало или нису правовремено дошли до информација о изменама у раду библиотеке, па будући да највећи број (природно) инсистира на слободном приступу фонду - нису желели или нису могли да користе услуге библиотеке. 
Графикон 2.

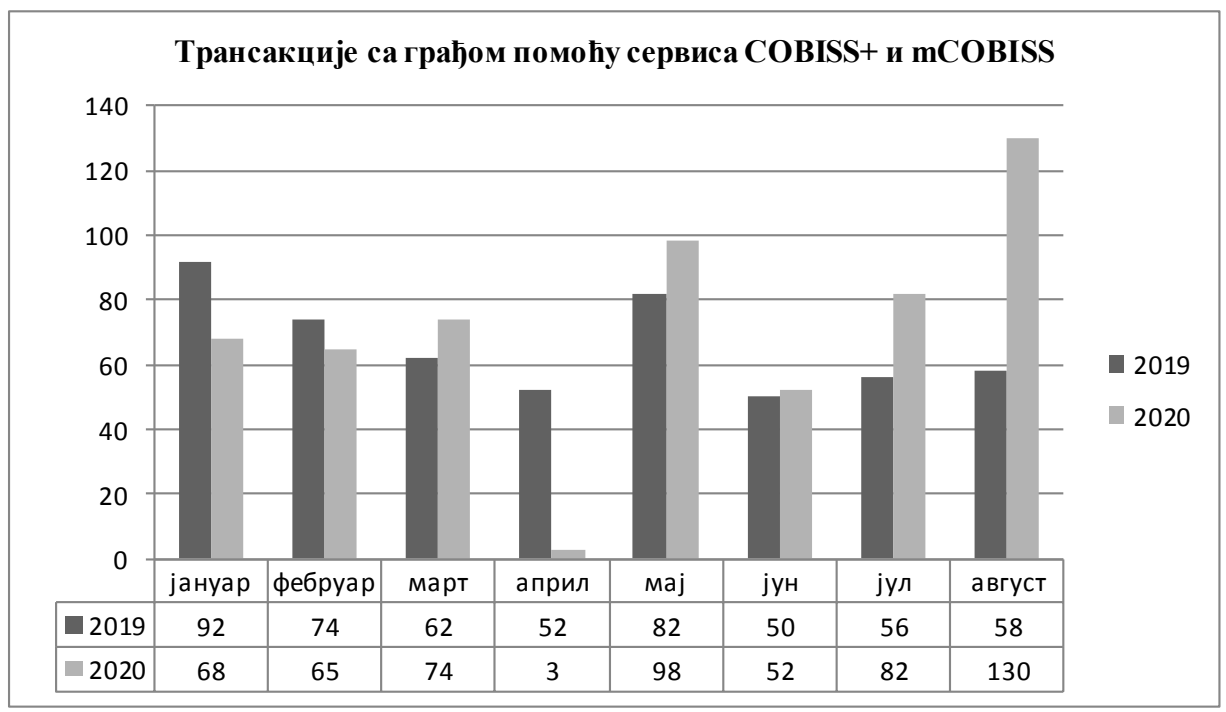

У Грабикону 1 приказане су све „трансакције” које су евидентиране у систему Кобис у самој библиотеци, приликом посете корисника, и односе се на позајмицу грађе ван библиотеке, за рад у читаоници, резервације, продужење рока позајмице, враћање грађе и сл. Види се да је тренд тих трансакција грађе у 2019. години у изабраном периоду релативно стабилан са благим падом у летњим месецима и у време годишњих одмора и летњег распуста. Први месеци у 2020. години не показују значајна одступања, да би се број трансакција грађе у марту преполовио због затварања библиотеке за кориснике средином марта, у априлу није било уопште посета, па самим тим ни евидентираних трансакција грађе; након отварања библиотеке за кориснике 11. маја, види се одмах пораст, а током наредних месеци благо колебање у бројкама које не досежу до оних у истом периоду прошле године. Разлоге су навели сами корисници који су долазили у овом периоду у библиотеку, али су из ње излазили без књиге: желели су да сами бирају то што ће читати и многи нису били спремни на то да прихвате препоруку библиотекара и сачекају да се књиге пронађу у фонду и донесу до „барикаде” направљене од столова на самом улазу у библиотеку. Осим тога, било је оних који су до ове „рампе” долазили „неспремни”, тј. нису имали никакав списак жеља за читање, нису претражили онлајн каталог библиотеке или нису прихватили ниједан од понуђених начина да књиге наруче. Свакако да је било и оних који су сматрали да долазак у библиотеку у условима 
које је наметнула пандемија - није безбедан. Пошто је 18. августа укинута ванредна ситуација у граду и библиотека поново ради са корисницима на уобичајен начин, уз примену прописаних здравствених мера, а од 1. септембра и читаонице, остаје да се у праћењу посета и коришћења фондова до краја године утврди шта је у ствари прави разлог. Страх свакако јесте присутан, али и чињеница да наши корисници не користе онлајн услуге библиотеке и поред детаљних упутстава на сајту о томе како се претражује каталог, како се отвара кориснички профил „Mој COBISS”, како се користи апликација за мобилни телефон mCOBISS; све информације о онлајн погодностима могу се добити и приликом посете библиотеци и разговора са библиотекаром, али и телефоном.

Бројке у Графикону 2 (односи се на резервације заузете и слободне грађе преко система COBISS+ и mCOBISS, те продужење и отказивање резервација) недвосмислено указују на то да се у наредном периоду морамо много више посветити и више ангажовати да упутимо кориснике у то да библиотечки онлајн сервиси доступни од куће јесу ту да олакшају многе активности везане за избор књига, резервације, продужење рока позајмице и сл., али се заиста морамо сложити и са тим да ништа не може заменити шеткање међу библиотечким полицама и листање књига, читање сажетака на корицама, тихи разговор о прочитаним књигама и другим темама, и све оно због чега боравак у библиотеци човеку у ствари јесте пријатан.

Међутим, и у време ванредног стања, у периоду од 16. марта до 11. маја, када библиотека није радила са корисницима, забележено је да је само десет корисника користило COBISS+ и то 30 пута - да би резервисали (шест пута) или продужили рок за враћање позајмљене грађе (24 пута).

Укупно у посматраном периоду (1. јануар - 1. септембар) у Грабикону 2, у 2019. години има 526 онлајн трансакција које је направило 79 чланова, а у 2020. години - 572 трансакције од 86 чланова.

Мора се рећи и ово: из читаве ове приче о корисницима, коришћењима и фондовима - изузета су четири огранка Народне библиотеке Бор у селима Злот, Брестовац, Кривељ и Доња Бела Река. Иако су неке од ових сеоских библиотека (Злот и Кривељ) „старије” од градске библиотеке и представљају заметке данашње библиотечко-информационе делатности не само у овом крају, већ и у читавој Србији и које су самим својим раним постојањем допринеле да се читалачка свест развије и одржи, а култура и знање постану потреба - оне су и данас, све до једне, без интернета, без телефонског прикључка и основних здравствено-санитарних услова. У онлајн каталогу њихови фондови су и даље невидљиви, а корисници се грађом задужују на „традиционални” начин, тако да се показатељи рада 
ових малих библиотека не могу пратити у сваком тренутку. Откада је проглашена пандемија и општа опасност од вируса короне, њихови корисници су у апсолутно неповољном положају у односу на кориснике градске библиотеке.

\section{Закључак}

Пандемија заразне болести ковид-19 изазвала је огромне промене у животима људи. Са једне стране, брига за живот и здравље принудила нас је да живимо у једној новој, измењеној реалности у којој важе другачија правила у готово свим сферама јавног и приватног живота. Са друге стране, након првог „удара”, у првој половини године, када су биле проглашене и најтеже мере изолације људи, природно се појавила потреба да се са животом настави, а за то је било потребно да се навикнемо на неке промене, а међу њима на првом месту на стално ношење заштитних маски у јавном простору и држање физичког растојања.

У вртлогу промена које су се одвијале, и то веома брзо, не остављајући много простора и времена за премишљања и колебања, и библиотеке су морале брзо да реагују и прилагоде пословање и постану спремне да у новим условима и даље унапређују своје услуге не би ли оправдале постојање у заједници у којој обављају своју делатност. То ће у блиској будућности сигурно постати императив, јер социјално дистанцирање и економски пад који се већ одражава на државни буџет, а тиме и локалне буџете, укључујући и финансије резервисане за јавне библиотеке, већ указују на то да ћемо, суочени пре свега са финансијским изазовима, морати да се окренемо оним професионалним, и уз знање које имамо и међусобну библиотекарску подршку и солидарност које смо већ показали - учинимо све да се превазиђе настали јаз, да микросвет који влада у библиотеци буде поново тих, миран и стабилан, а корисници задовољни.

Не зна се колико ће све ово још трајати. До сада се показало да је ток пандемије прилично непредвидљив. Међу књижевним делима која описују тренутке у којима смо се сада сви нашли, можда је најупечатљивија Камијева Куіа, књига које тренутно нема на листи најчитанијих 50 у Народној библиотеци Бор, нити се исто може рећи и за неке друге са темом „контаминације” (Сарамагово Слейило, Пекићево Беснило, Маркесова Љубав у gоба колере итд.). Симболика ових литерарних инфекција обично указује на нешто друго, на неки много шири и дубљи проблем. И штета је што је Камијева Куїа од почетка године позајмљена само шест пута: куга (ковид - зараза, свакако) на крају биће побеђена, врата града отворена, а 
преживели грађани играће на трговима. Ипак: И слушајућu pagocну ірају

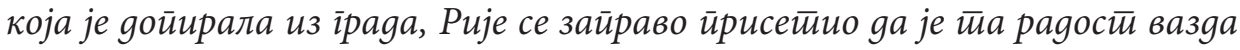
уірожена. Јер је он знао оно шито ово разяраїано мношитво свеита није знало, а шито се може иррочитиаии у книїама: gа бацил куіе никаg не умире нитии ишчезава, gа се може деценијама ӣритиајити у намешитају и рубль, gа он стиритьиво чека у собама, у иоорумима, шкрињама, марамицама или стиарим харииијама, и gа ће, можgа, gоћи gан каg ће, на несрећу љуgи и юима за наук,

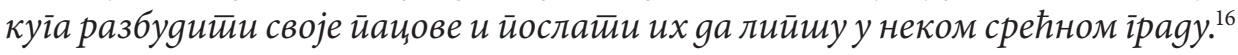
Треба мислити о овоме и марљиво радити, прилагођавати услуге библиотеке и - бити спремни на све.

16 Alber Kami, Romani (Beograd: Paideia, 2007), 360. 


\section{Literatura:}

1. Deutscher Bibliotheksverband (dbv), „Coronavirus: Bibliotheken bieten weiterhin Zugang zu Information und Medien", https://wwwbibliotheksverband.de/dbv/ presse details/archive/2020/march/article/coronavirus-bibliotheken-bieten-weiterhin-zugang-zu-information-und-medien.html (preuzeto 31. 8. 2020).

2. Kami, Alber. Romani. Beograd: Paideia, 2007.

3. NAPLE Sister Libraries, „Libraries in Times of Coronavirus: the Case of Public Library of Pittem (Belgium), https://www.naplesisterlibraries.org/libraries-in-times-of-coronavirus-the-case-of-public-library-of-pittem-belgium/ (preuzeto 5. 9. 2020).

4. Narodna biblioteka Bor, „Ne učestvovati. Ne prilagođavati se.”, https://www.biblioteka-bor.org.rs/2020/03/ne-ucestvovati-ne-prilagodjavati-se/ (preuzeto 6. 9. 2020) (na ćirilici)

5. Narodna biblioteka Bor, „Prljave knjige”, https://www.biblioteka-bor.org.rs/2020/04/ povodom- svetskog-dana-knjige/ (preuzeto 6. 9. 2020) (na ćirilici)

6. WHAT COULD/SHOULD CURATING DO?-WCSCD, http://wcscd.com/index. php/about-wcscd/ (preuzeto 1. 9. 2020).

7. WHAT COULD/SHOULD CURATING DO? -WCSCD, "The Public Library Bor”, http://wscsd.com/index.php/cells/ (preuzeto 1. 9. 2020).

8. WHAT COULD/SHOULD CURATING DO?-WCSCD, Zijin Bor Mining Case Study, http://wscsd.com/index.php/projects/zijin-bor-mining-case-study/ (preuzeto 1. 9. 2020).

9. WHAT COULD/SHOULD CURATING DO?-WCSCD, Infrastructuring the Region: The City of Bor, http://wscsd.com/index.php/projects/infrastructuring-the-region-the-city-of-bor/ (preuzeto 1. 9. 2020).

10. WHAT COULD/SHOULD CURATING DO?-WCSCD, „On Bor's Industrial Heritage", http://wscsd.com/index.php/wcscd-curatorial-inquiries/as-you-go-journal/ on-bors-industrial-heritage/ (preuzeto 1. 9. 2020). 


\author{
Ana Janković \\ Public Library Bor \\ ana.jankovic67@gmail.com
}

\title{
PUBLIC LIBRARIES AND THEIR ACTIVITIES IN THE TIME OF PANDEMIC CRISIS
}

\begin{abstract}
The paper explores activities of public libraries under changed conditions caused by the official announcement of the infectious disease COVID-19 pandemic, paying special attention to the work of the Public Library Bor during the lockdown and afterwards. Public libraries worldwide had to find a way to continue their work and to overcome fears, confronting contradictory information, as well as to make, often alone, hard decisions of what services to offer and how to deliver materials to users. Libraries were deciding on options ranging from minimal restrictions to the total lockdown. On the other hand, library users had to turn to online sources of information and services in order to satisfy their needs and interests, so that the paper also explores the effects of these new working conditions on the usage of digitized materials and virtual library services. The conclusion is that libraries should carefully evaluate their possibilities and resources, adjusting their services and programs to what people need the most. As the course of the pandemic is constantly changing, libraries need to focus on improving their virtual offers and finding the way to do so with minimum and tolerable expenses, having in mind that many public libraries in Serbia have already faced budget reductions and cuttings.
\end{abstract}

Keywords: public library, pandemic, library resources, users' habits, online services.

Примљено: 9. септембра 2020.

Прихваћено: 8. октобра 2020. 